\title{
Migration Analysis and Regional Population Projections
}

\author{
JON INGE LIAN \\ KNUT SØRENSEN
}

\section{Regional population projections in Norway}

In Norway we have produced regional population projections for some time. The projection model is a standard component model at a rather detailed regional level (ca. 100 regions). Migration is "modeled» assuming fixed rates of gross outmigration and a fixed distribution of migrants among regions. These parameters are calculated from a base period, usually of four years. The results are then broken further down to the 454 municipalities.

Usually, we have not produced projections with alternative migration assumptions, although we make an alternative where we disregard migration altogether. We also make the county administrations an offer to run our breaking down model on the county level with their own parameters.

For some time we have been working on a system of models called DRØM (Demographic, Regional-Economic Model system) to supplement the traditional population projections. The analysis of net (and to some extent gross) migration undertaken in the implementation of this system is reported in the second section of this paper.

The DRØM model system produces an alternative population projection where migration is influenced by regional labor market development. So, this development has to be projected. The labor market projection of DRØM is designed to give regional breakdowns of the results of the national models. The results of the national economic planning model are broken down by county by means of a regional economic model called REGION. There also exists a national model of labor supply (MATAUK), whose results are broken down by county in a DRØM premodel (Figure 1).

The regional economic model REGION is an independent model that has been operative for some years. It is, however, not as well established in the planning process as the national models.

The DRØM Pre-model has only recently been made operative, and documentation has not yet been published. This pre-model is also intended for use in a slightly different setting. Regional labor supply projections are then based on a given regional population projection. Regional labor supply parameters are given exogenously, and can (optionally) be adjusted so as to be consistent with results from MATAUK. This will probably be among the main uses of the DRØM models.

The calculations of the integrated part of DRØM proceeds as a standard cohort component model, except for the migration part.

The balance in the regional labor market is estimated on the basis of labor demand figures derived from REGION and labor supply derived from the DRØM Premodel.

The labor market situation is used to estimate net migration for each of the two age groups 16-24 and 25-49 years. Gross out-migration (one-year age groups, both sexes) is calculated assuming fixed rates of out-migration. In-migration to each of the broader age groups is found residually. It is distributed by (one-year) age and sex as in a base period. In-migration of children is made to depend on in-migration of the adults (25-49 years). 
F i g u r e 1. The DRØM Model System.

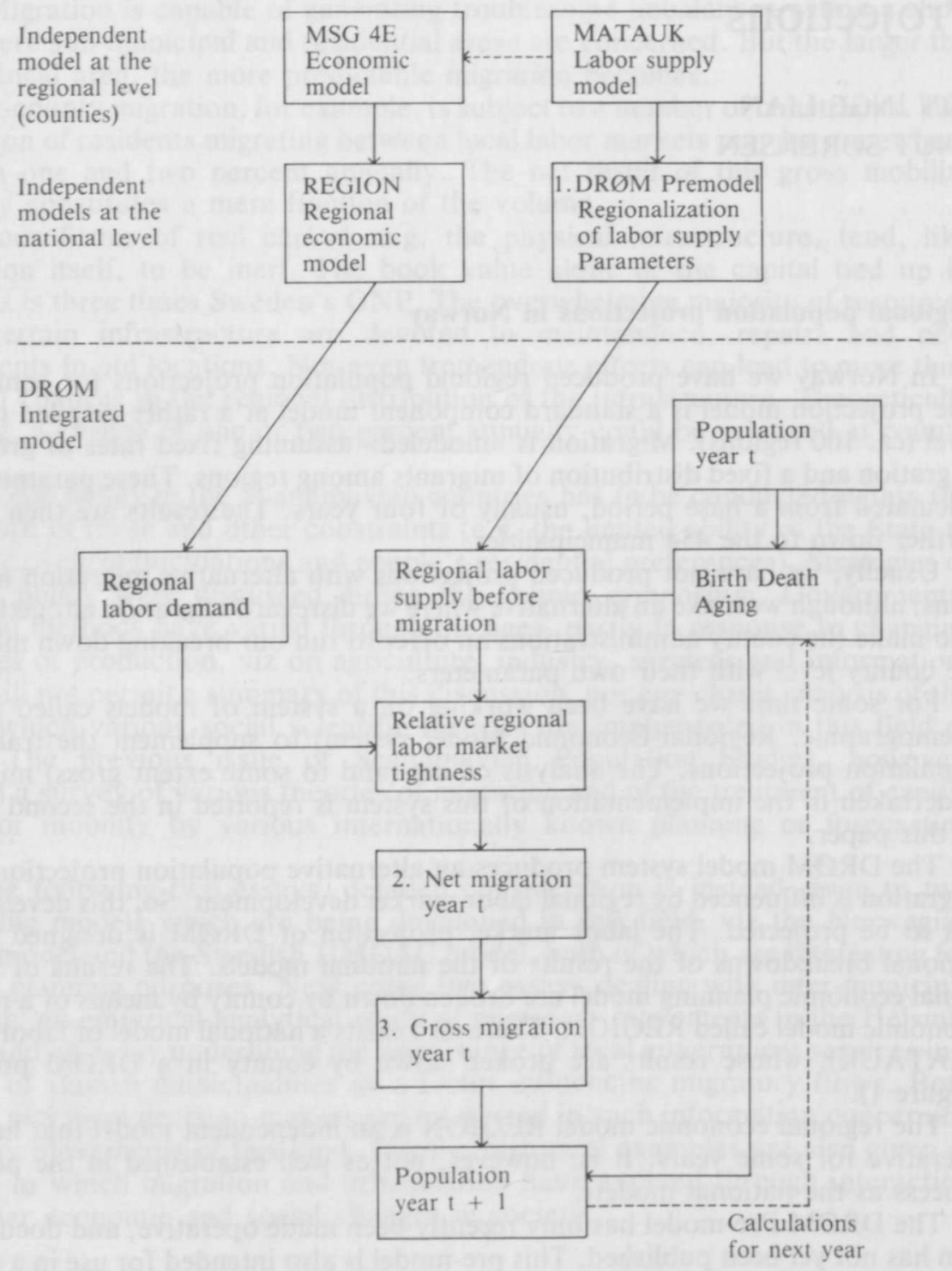

The gross migration calculation serves to distribute the projected net migration for the broader age groups by one-year groups. We are considering to utilize more of the results of the analysis described in part two of this paper.

The DRØM integrated model is in the process of being tested.

\section{Migration analysis in DRØM}

\section{A theoretical discussion}

Most attempts to model internal migration at an aggregate level have started with the labor market as a key factor. This may be for theoretical reasons, or due to problems connected with forecasting regional trends of other factors. 
The international literature is, however, ambiguous on the relationship between labor market and internal migration (Greenwood 1975). Fields (1976) suggests that probabilities of acquiring and retaining employment is a better measure of potential migration than unemployment rates. Thus labor turnover may provide a better explanation for migration rates than the conventionally used unemployment rate. Moen (1980) points out that there are several types of unemployment that is not likely to lead to migration (frictional, seasonal or social unemployment). In addition unemployment affects only few people while migration concerns many. Different commuting patterns, unemployment registration rates, timelags in responses and attitudes towards migration may also disturb the relationship between unemployment and migration. In spite of this, Moen found a clear negative relationship between net migration and unemployment rates in Norwegian counties in the 1970s.

Greenwood (1975) says about gross migration that: "A finding common to a number of gross migration studies is that income (and job) opportunities provide a better explanation of in-migration than they do of out-migration". He also concludes that: »One of the most perplexing problems confronting migration scholars is the lack of significance of local unemployment rates in explaining migration». The fact that many studies use an end-of-period unemployment rate to explain migration that occurred over the period has been suggested as one possible cause of the problem. Migration rates change slowly and previous migration may itself influence the economic conditions not only in the end of a regression period but also in the actual year at study. Areas with bad economic conditions whave relatively few recent in-migrants and the population of such places tend to be relatively immobile (since the more mobile have presumably already left).... Just the opposite situation exists in areas where conditions are attractive to migrants, because where inmigration rates tend to be high, out-migration rates also tend to be high.» Kykkä et. al (1978) has a simular result from Finland. However, many results like this can be explained if one takes the selectivity of migration into account. Age and educational training are the most important factors in this aspect.

At this point we conclude that at an aggregate level labor market conditions do have an effect on migration, especially net-migration.

Studies at micro level, like the Norwegian Survey of Migration Motives 1972, show the complexity of migration flows. Factors like migration distance and direction (rural-urban) and personal characteristics of the migrants like age, education and family situation all are important. This complexity of migration flows makes it natural to question the utility of crude studies at an aggregate level in gaining insight in the migration processes.

However, do we really have any alternatives in population projections? In addition, answers to such surveys may have an »egocentric bias». The respondents often mention the last personal argument in a chain of causes and take political or economical conditions that may affect migration decisions as granted. So, in spite of the complexity of migration flows at an individual level, the net result at an aggregate level may be more simple. We must, however, be cautious when we derive from macro to micro level (and opposite). There is, of course, no such person as a netmigrant. Anyhow, the surveys may indicate factors which are worth modeling at an aggregate level. The Norwegian Survey of Migration Motives 1972 pointed on the following major migration motives:

labor market conditions
housing and environment
education
family
other causes

\begin{tabular}{|c|c|}
\hline & ercent \\
\hline 35 & $"$ \\
\hline 9 & ") \\
\hline 12 & " \\
\hline 0 & ") \\
\hline
\end{tabular}

Moves caused by motives related to housing were short moves, while moves related to labor and educational motives were long. In our analysis we have concentrated on labor, housing and educational conditions as background factors. Belief in these 
factors as decisive for migration across county borders, and problems with data availability made this choice natural.

\section{Data}

The migration rates are compiled from annual counts of the population register. People living in different counties at the beginning and the end of a year are defined as migrants. A migration rate is calculated as the number of migrants per 1000 inhabitants. We use such rates both for gross out- and in-migration, and for net migration, covering each of the two age groups 16-24 (youth) and 25-49 (adults).

The labor market indicator $\left(\mathrm{X}_{\mathrm{j}, \mathrm{t}}\right)$ is calculated as the difference between the regional and national tightness in the labor market.

$$
\mathrm{X}_{\mathrm{j}, \mathrm{t}}=\frac{\mathrm{D}_{\mathrm{j}, \mathrm{t}}}{\mathrm{S}_{\mathrm{j}, \mathrm{t}}}-\frac{\sum_{\mathrm{j}} \mathrm{D}_{\mathrm{j}, \mathrm{t}}}{\sum_{\mathrm{j}} \mathrm{S}_{\mathrm{j}, \mathrm{t}}}
$$

where $\mathrm{S}$ is the supply and $\mathrm{D}$ is the demand for labor, and $\mathrm{j}, \mathrm{t}$ is indexes for county, year. The supply of labor is taken from an analysis of the Labour Force Survey. The demand for labor is defined by: $\mathrm{D}=\mathrm{S}+\mathrm{V}-\mathrm{U}$ where $\mathrm{V}$ is vacancies and $\mathrm{U}$ is unemployment reported to labour offices. The labor market indicator is thus very sensitive to the registration rate of vacancies and unemployment. This labor market indicator was made and first used by Brun (1982).

The building of new dwellings per adult (19-65 years) is used as an indicator of housing conditions. Attempts to construct a similar indicator of the tightness of the housing market as for the labor market created several problems. Housing frequencies and housing demolition had to be estimated. The main and decisive problem was, however, too little variation over time in the housing indicator.

Educational possibilities is measured by the number of pupils and students engaged in all education beyond the nine year basis education per youth $(16-24$ year).

The regression also included a dummy variable for the year 1970, when the reported migration rates due to the census, were higher than normal.

\section{The regression model}

The following model has been used by Trønnes (Trønnes, 1983). To simplify the formal presentation, only the simplest version of the model is stated.

$$
\mathrm{Y}_{\mathrm{j}, \mathrm{t}}=\mathrm{a}_{\mathrm{j}}+\mathrm{bX}_{\mathrm{j}, \mathrm{t}}+\mathrm{u}_{\mathrm{j}, \mathrm{t}}
$$

where $\mathrm{j}$ and $\mathrm{t}$ are indexes for county and year

$$
\begin{aligned}
& \mathrm{Y}_{\mathrm{j}, \mathrm{t}}=\text { migration rate } \\
& \mathrm{X}_{\mathrm{j}, \mathrm{t}}=\text { labor market indicator } \\
& \mathrm{a}_{\mathrm{j}}=\text { county-specific constant term } \\
& \mathrm{b}=\text { the parameter of the labor market indicator } \\
& \mathrm{u}_{\mathrm{j}, \mathrm{t}}=\text { residuals }
\end{aligned}
$$

The correlations of the residuals may have a time and space dimension. We disregard the spatial autocorrelation and assume that the residuals follow a 1 st order autoregressive process.

$$
\mathrm{u}_{\mathrm{j}, \mathrm{t}}=\mathrm{Ku}_{\mathrm{j}, \mathrm{t}-1}+\mathrm{d}_{\mathrm{j}, \mathrm{t}} \text {, where the residuals } \mathrm{d}_{\mathrm{j}, \mathrm{t}} \text { are independent normal- }
$$

The parameters $\mathrm{b}$ and $\mathrm{K}$ are assumed to be the same in all counties. By multiplying equation (1) for time $\mathrm{t}-1$ with $\mathrm{K}$ and subtracting the result from (1) we get:

$$
\mathrm{Y}_{\mathrm{jt}}=\mathrm{c}_{\mathrm{j}}+\mathrm{KY}_{\mathrm{j}, \mathrm{t}-1}+\mathrm{bX}_{\mathrm{j}, \mathrm{t}}-\mathrm{KbX}_{\mathrm{j}, \mathrm{t}-1}+\mathrm{d}_{\mathrm{j}, \mathrm{t}}
$$

where $c_{j}=(1-K) a_{j}$ 
Model (3) is equivalent to (1) and (2). Regressions on (3) give consistent estimates on both the parameters and variance of the residuals in model (1). The formulation (3) can also be derived in a more formal way by assumptions about unobserved variables (Trønnes 1983).

The county-specific constant terms of the model capture the heterogenity across regions in the average level of the migration rates. The variance reduction is therefore mainly due to the ability of the explanatory variables to account for the evolution over time of the migration rates.

The model with several explanatory variables is quite analogous to (1)-(3), considering the parameter $\mathrm{b}$ and the variable $\mathrm{X}_{\mathrm{i}, \mathrm{t}}$ to be suitable vectors.

To help evaluating the results, we have developed a special measure, expressing the reduction in residual variance achieved by going from a simple model, disregarding the explanatory variables, to the full model (3). The simple model is:

$$
Y_{j t}=a_{j}+v_{j, t}
$$

where $v_{j t}=K_{1} v_{j, t-1}+e_{j, t}$, and $e_{j, t}$ are independent normally distributed residuals. The variance reduction achieved by turning from model (1) to (4) is:

$$
\mathrm{R}_{\mathrm{x}}^{2}=\frac{\operatorname{Var}\left(\mathrm{v}_{\mathrm{j} t}\right)-\operatorname{Var}\left(\mathrm{u}_{\mathrm{j}, \mathrm{t}}\right)}{\operatorname{Var}\left(\mathrm{v}_{\mathrm{j}, \mathrm{t}}\right)}=1-\frac{\operatorname{Var}\left(\mathrm{U}_{\mathrm{j}, \mathrm{t}}\right)}{\operatorname{Var}\left(\mathrm{V}_{\mathrm{j}, \mathrm{t}}\right)}
$$

All models were estimated applying an iterative non-linear least squares routine from the package TROLL, to the model (3). The model is non-linear, owing to restrictions on the coefficients of (3).

The parameters of model (1) can be consistently estimated by the ordinary least squares method (OLS). The estimate of the residual variance is then, however, biased. The usual $\mathrm{R}^{2}$ measure tends to be too high when autoregression is important.

\section{Some results}

Regression analysis for the period 1969 - 79 was performed for the age groups 16-24 years and 25-49 years for both sexes. According to Trønnes (1983) and Stordahl (1983) this is a natural choice since migration patterns of youth (16-24 years) differs from other age groups. In addition migration motives also differ between youth and adults as a reflection of different life-cycle phases. Labor and educational conditions dominate as migration motives of the youth, while dwelling and environment conditions becomed more important in the older and more established age groups.

In Tables $1-3$ (p. 174), $\mathrm{R}_{\mathrm{x}}^{2}$ is our measure of variance reduction comparing the full model to the simple one of only regional constant terms. $R_{d}^{2}$ is the usual measure of explained variance of the full model, consistently estimated.

The total explanation, $\mathrm{R}_{\mathrm{d}}^{2}$, is high due to a model formulation with countyspecific constant terms, capturing most of the differences in the average level of the migration rates between counties. In general, the migration rates varies more between counties than they do over time.

A main result is that the labor market conditions seem to have a larger effect on net-migration than on gross-migration. The effect is particularly strong on youth net-migration. The labor market further seems to affect adult in-migration and youth out-migration rates, while the influence on adult out-migration and youth inmigration is rather small. Since the young age groups are about to enter the labor market while the adults are already established, it makes sense that changes in the labor market in an area affect youth out-migration rates in the same area more than adult out-migration. In the case of in-migration one possible explanation is that adults have better qualifications and information on the labor market than youth 
$\mathrm{T}$ a b 1 e 1 . In-migration and labor market, housing and educational conditions. Estimated t-values.

\begin{tabular}{|c|c|c|c|c|c|c|}
\hline \multirow{2}{*}{ Age/sex } & \multirow[b]{2}{*}{$\mathrm{R}_{\mathrm{x}}^{2}$} & \multirow[b]{2}{*}{$\mathrm{R}_{\mathrm{d}}^{2}$} & \multirow{2}{*}{$\begin{array}{l}\text { Auto- } \\
\text { correlation } \\
\text { coefficient }\end{array}$} & \multicolumn{3}{|c|}{ Estimated $t$-values } \\
\hline & & & & $\begin{array}{l}\text { Labor } \\
\text { market }\end{array}$ & $\begin{array}{c}\text { Hous- } \\
\text { ing }\end{array}$ & $\begin{array}{c}\text { Educa- } \\
\text { tion }\end{array}$ \\
\hline \multicolumn{7}{|c|}{$16-24$ years } \\
\hline Both sexes & .291 & .92 & .37 & 3.31 & 1.07 & -4.48 \\
\hline Males & .228 & .90 & .43 & 2.57 & 0.60 & -3.77 \\
\hline Females & .291 & .90 & .29 & 3.26 & 0.85 & -4.97 \\
\hline \multicolumn{7}{|c|}{$25-49$ years } \\
\hline Both sexes & .331 & .84 & .48 & 5.29 & 3.60 & 0.26 \\
\hline Males & .307 & .81 & .46 & 5.29 & 2.99 & 0.80 \\
\hline Females & .338 & .85 & .42 & 5.11 & 4.25 & 0.51 \\
\hline
\end{tabular}

$\mathrm{T}$ a b l e 2. Out-migration and labor market, housing and educational conditions. Estimated t-values.

\begin{tabular}{lcccccc}
\hline & & & & & \multicolumn{3}{c}{ Estimated t-values } \\
\cline { 5 - 7 } Age/sex & $\mathrm{R}_{\mathrm{r}}^{2}$ & $\mathrm{R}_{\mathrm{d}}^{2}$ & $\begin{array}{c}\text { Auto- } \\
\text { correlation } \\
\text { coefficient }\end{array}$ & $\begin{array}{c}\text { Labor } \\
\text { market }\end{array}$ & $\begin{array}{c}\text { Hous- } \\
\text { ing }\end{array}$ & $\begin{array}{c}\text { Educa- } \\
\text { tion }\end{array}$ \\
\hline 16-24 years & & & & & & \\
Both sexes & .313 & .90 & .31 & -6.80 & 0.40 & -3.31 \\
Males & .275 & .87 & .37 & -6.94 & 0.80 & -1.90 \\
Females & .160 & .88 & .42 & -5.12 & 1.27 & -1 \\
25-49 years & & & & & & \\
Both sexes & .096 & .93 & .22 & -3.55 & 2.05 & 2.22 \\
Males & .085 & .90 & .19 & -3.49 & 2.28 & 1.76 \\
Females & .095 & .94 & .23 & -3.14 & 1.52 & 2.56 \\
\hline
\end{tabular}

' Not included. The estimation routine did not converge.

$\mathrm{T}$ a b l e 3. Net-migration and labor market, housing and educational conditions. Estimated t-values.

\begin{tabular}{|c|c|c|c|c|c|c|}
\hline \multirow[b]{2}{*}{ Age/sex } & \multirow[b]{2}{*}{$\mathrm{R}^{2}$} & \multirow[b]{2}{*}{$\mathrm{R}_{\mathrm{d}}^{2}$} & \multirow{2}{*}{$\begin{array}{l}\text { Auto- } \\
\text { correlation } \\
\text { coefficient }\end{array}$} & \multicolumn{3}{|c|}{ Estimated $\mathrm{t}$-values } \\
\hline & & & & $\begin{array}{c}\text { Labor } \\
\text { market }\end{array}$ & $\begin{array}{l}\text { Hous- } \\
\text { ing }\end{array}$ & $\begin{array}{c}\text { Educa- } \\
\text { tion }\end{array}$ \\
\hline \multicolumn{7}{|l|}{$16-24$ years } \\
\hline Both sexes & .406 & .88 & .05 & 9.48 & 1.52 & -0.78 \\
\hline Males & .362 & .86 & .07 & 8.63 & 1.44 & -1 \\
\hline Females & .351 & .85 & .01 & 8.51 & 1.91 & 0.02 \\
\hline \multicolumn{7}{|l|}{$25-49$ years } \\
\hline Both sexes & .350 & .81 & .38 & 7.49 & 2.25 & -1.11 \\
\hline Males & .334 & .74 & .34 & 7.54 & 1.51 & -1.09 \\
\hline Females & .316 & .84 & .33 & 6.52 & 2.88 & -2.09 \\
\hline
\end{tabular}

1 Not included. The estimation routine did not converge. 
and therefore could react to opening possibilities by moving in a more adequate way.

House-building and educational possibilities seem to affect only in-migration. In particular the effect of educational possibilities on youth in-migration rates seem high. This is surprising since, according to the rules of Norwegian population registration, educational moves are not to be registered unless the students either are married or take permanent work.

The signs of the estimated educational coefficients are all negative. This may be a reflection of national trends in the 1970s with decreasing mobility and increasing educational possibilities. Further, with fixed educational capacity in a county, increased in-migration would decrease the educational possibilities (per inhabitant).

In the projection model we have chosen a net-migration model with the labor market indicator as the only explanatory variable. A net migration relation is chosen on basis of the above results and a belief that the size of the population in a region in the long run has to adapt through net migration to the possibilities of finding employment.

Looking at the estimated constant terms in the net migration relation, we get an impression of how other factors than the labor market affect migration rates. It seems that for reasons other than the labor market young people move in an urbanizing way, while adults move to peripheral or rural counties. This may be an indication of the importance of educational and social conditions for youth migration, while housing and environmental conditions seem important for adults. For projection purposes we ought to have a priori assumptions on the grouping of counties based on knowledge about non-economic factors and their effect on migration rates.

Alternatively we could incorporate some of these factors in the projection in order to reduce the importance of the county specific constant term. We have, however, no convincing way to project housing supply and educational supply.

An attempt to do so would create several problems. How shall information on future plans of building of schools and dwellings be obtained? Do plans manifest themselves in actual building? How shall consensus on the assumptions be reached? However, if these problems were solved, the model could function as a consequence analysis of political aims. Since housing and educational variables, as we have expressed them, seem to have a much weaker effect on migration rates than the labor market, we are inclined to exclude them at this stage of development of the projection model. The estimation of the remaining labor market effect on migration may however be biased if the excluded factors are correlated with the labor market indicator. These correlations were rather small in our case. The relevant correlation coefficients all had absolute values less than 0.3 .

\section{Concluding remarks}

Migration is a major source of uncertainty in the projection of population development in small regions. Yet this has not led to a systematic testing of alternative assumptions about migration in Norwegian regional population projections. One reason why this is so, may be the implicit nature of these parameters of migration in the ordinary projection model.

The structural pattern of migration in the base period is only indirectly represented by the migration rates and the in-migrant distribution. It is not evident what kind of changes in these parameters that will produce an interesting projection alternative. The explicit link between migration and labor market conditions in DRØM opens up possibilities for more meaningful specifications of migration alternatives.

Many of our central users appreciate an attempt to see regional population and labor market in relation to national long term economic and demographic pros- 
pects. To some extent, we have achieved this by establishing links to the existing national planning models.

The DRØM model system will, however, be more complex than the present population projections. This is particularly the case when the system, including the models at the national level, is seen as a whole. We think our ordinary population projection model by now is considered fairly simple and comprehensible by the most important users. We hope that the extension to the integrated part of the DRØM model system shall not be too hard to understand. However, other parts of the model system, particularly the economic models, are complex and involves a large number of assumptions. These assumptions can at best be quite summaribly described in the documentation of the population projection results.

On the other hand, each of the independent models also have their own documentation. There also will exist documentation of the specific model runs that we may plan to utilize. As an example we may mention the so-called basic alternative of the long-run perspectives of Norwegian economy published in the series of official reports (NOU). This is a national economic projection, which is more or less known to the Norwegian planning establishment. By using model runs that are documented in other contexts, we hope to achieve some division of labor in our description of these models and their results. Yet it seems likely, that users not aquinted with these models will find it difficult to see through our calculations.

We consider population projection using the DRØM model system as an interesting, but possibly controversial supplement to our regular projections. The main benefit from of our project may well stem from our regional labor market projections.

\section{References}

Brun, Stein Erland. (1982). Nettoflytting og arbeidsmarked i fylkene. En foreløpig analyse av sammenhenger. Rapporter 82/6. Statistisk Sentralbyrå, Oslo.

Fields, Gary S. (1976). Labour force migration, unemployment and job turnover. The Rew. of Ec. and Stat., 407-415.

Greenwood, Michael J. (1975). Research on internal migration in the United States: a survey. Journ. of Ec. Lit., Vol. 397-434.

Kykkä, Sirpa; Ojala, Veijo; Paasivirta, Anssi and Sundroos, Anders. (1978). Flyttningsrörelsen och levnadsvillkoren - en beskrivning av den interna flyttingen i Finland. Bilaga II till slutrapport från NordREFO's preferenser och levnadsvillkor. NordREFO 1978: 3. Statsrådets kansli, Helsingfors.

Moen, Kjetil. (1980). Om sammenhengen mellom flytting og arbeidsløshet. In: Plan og arbeid, nr. 5, 1980, pp. $247-251$.

Stordahl. (1983). Flyttemønstre i Norge 1971-1974. Samfunnsøkonomiske Studier (SøS) nr. 50. Statistisk Sentralbyrå, Oslo.

Trønnes, Dag Helge. (1983). Bruttoflytting og arbeidsmarked i fylkene. Internt notat 83/28. Statistisk Sentralbyrá, Oslo. 